\title{
Identification, Geographical Distribution and Hosts of Subterranean Termites in the United Arab Emirates Arid Ecosystem
}

\author{
W. Kaakeh \\ Department of Arid Land Agriculture, College of Food Systems, \\ P. O. Box 17555, United Arab Emirates University, \\ Al-Ain, United Arab Emirates
}

وليد كعك

الخلاصة: تم تعريف ستة أنواع من النمل الأبيض (الأرضة) تابعة إلى خمسة أجناس وثلاث فصائل (هودوزرميتيدي Hodotermitidae،

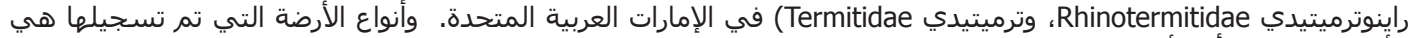
الأرضة الحاصدة أو الأرضة اللاشوكية (Anacanthotermes ochraceus (Burmeister و (Anacanthotermes ubachi (Navas)، وأرضة الرمل الثغرية Psammotermes hypostoma (Desneux)، والأرضة الشمعية الصغيرة Microcerotermes diversus) (Silvestri )، والأرضة النجدية الدقيقة (Microtermes najdensis (Harris) ، والأرضة (Heterotermes aethiopicus (Sjostedt)،

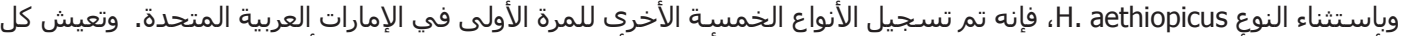

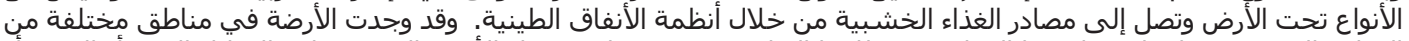

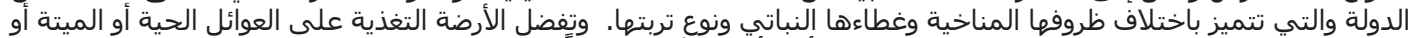
A. ochraceus المتعفنة، بالإضافة إلى المواد غير السيليلوزية.

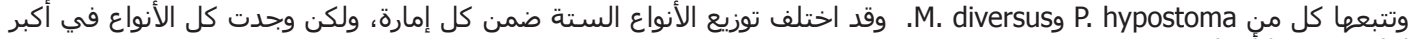
إمارتين وهما أبوظبي ودبي

ABSTRACT: Six termite species, belonging to five genera and three families (Hodotermitidae, Rhinotermitidae and Termitidae) were identified in the United Arab Emirates (UAE). Termite species recorded were the harvester termites Anacanthotermes ochraceus (Burmeister) and Anacanthotermes ubachi (Navas), the sand termite Psammotermes hypostoma (Desneux) and the small waxy termites Microcerotermes diversus (Silvestri), Heterotermes aethiopicus (Sjostedt), and Microtermes najdensis (Harris). Except for a previous record of H. aethiopicus, the other five species were recorded for the first time in the UAE. All species were subterranean in habitat and reach wood sources through earthen gallery systems. Termites were available in areas with varied conditions of climate, vegetation and soil types. Termites showed host preference for dead, living, or decaying plant materials and non-cellulose materials. The dominant termite species recorded was $A$. ochraceus, followed by $P$. hypostoma and $M$. diversus. The distributions of the six termite species varied in each of the seven Emirates. All species were present in the two largest Emirates of Abu Dhabi and Dubai.

Keywords: Anacanthotermes ochraceus, Psammotermes hypostoma, Arabian region, termite distribution, Isoptera, Rhinotermitidae, Hodotermitidae.

\section{Introduction}

Termites have become increasingly important pests of crops and buildings in the United Arab Emirates (UAE), where desert and marginal lands are irrigated for agriculture. UAE also imports many kinds of woods and wood products to meet the needs of industry, new buildings, construction and furniture.

Two termite foraging strategies are adopted in the UAE ecosystem: species are either nocturnal or they construct protective soil tunnels within which they are shielded from heat and desiccating effects of the sun. Termites feed on living, dead or decaying plant material. Some species are capable of reducing wooden structures to dust and may cause serious damage to buildings.

Several records pertaining to termites in the Arabian Gulf countries, especially in Saudi Arabia, have been made (Nasr et al., 1978; Badawi et al., 1982, 1986; Chhotani and Bose, 1982 and 1991). The termite fauna of the Arabian Peninsula comprise 22 species (Badawi et al., 1986; Chhotani and Bose, 
1991). No study of the termite fauna in the UAE has previously been made; the only record for UAE is a colony of Heterotermes aethiopicus (Sjostedt) infesting a house in Al-Ain City in Abu Dhabi Emirate (Boocock, 1979).

The objectives of this study were to conduct a general survey for identifying subterranean termites, to determine the geographical distribution of all termite species in all seven emirates, and to determine termite living- or dead-hosts.

\section{Materials and Methods}

Field sampling of termites from different regions of the UAE were conducted from March 2000-May 2002 (Figure 1). A total of 64 field trips were made in all Emirates (35 in Abu-Dhabi, 10 in Dubai, 8 in Sharjah, 4 in Ajman, 2 in Al Fujayrah, 3 in Umm al Qaywayn, 2 in Ras al Khaymah Emirate). A total of 224 sites (live or dead plant host or other infested materials) were inspected for termite presence: 115 in Abu-Dhabi, 46 in Dubai, 25 in Sharjah, 12 in Ajman, 14 in Al Fujayrah, 6 in Umm al Qaywayn, 12 in Ras al Khaymah Emirate. The number of field trips was consistent with the size of the each emirate. Direct collection of termites was made from all infested plants and materials. Termite specimens were mostly workers or nymphs, and to a lesser extend winged termites. Winged adults of most species were collected after their swarming periods (during a humid day or at night at the beginning of the spring). Soldiers and winged castes were only collected during the spring season at the time of termite swarming. Specimens were kept in $70 \%$ alcohol, each in a separate glass vial for each site in each emirate.

Preliminary identification of the collected termites was made using the available termite keys (Snyder, 1949; Harris, 1967; Fontes, 1985; Sands, 1998). The confirmation of termite identification was made by sending specimens to the British Museum of Natural

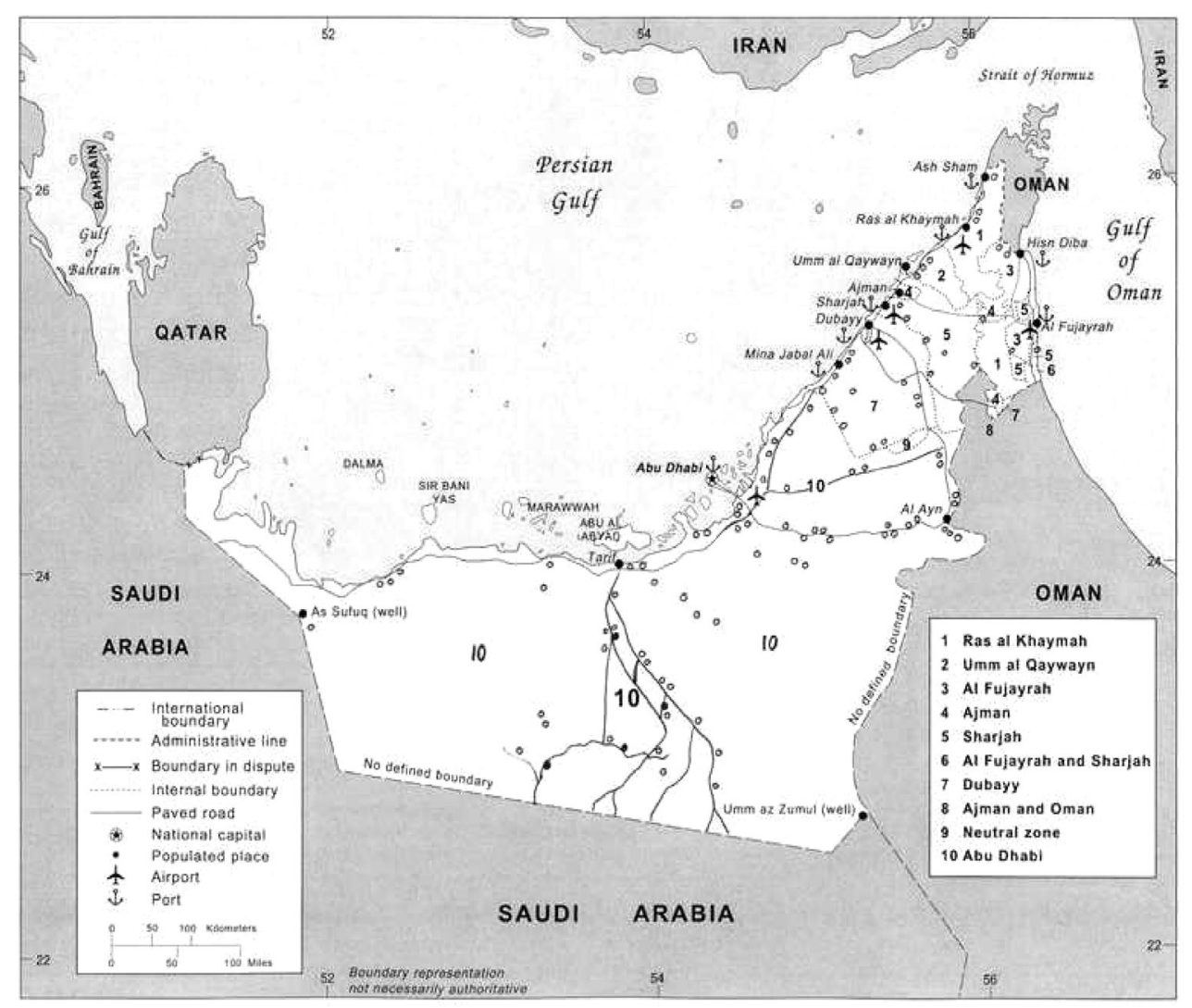

Figure 1. Map of the United Arab Emirates. Each circle symbol, in each Emirate, represents 1-3 inspected sites in each location. 


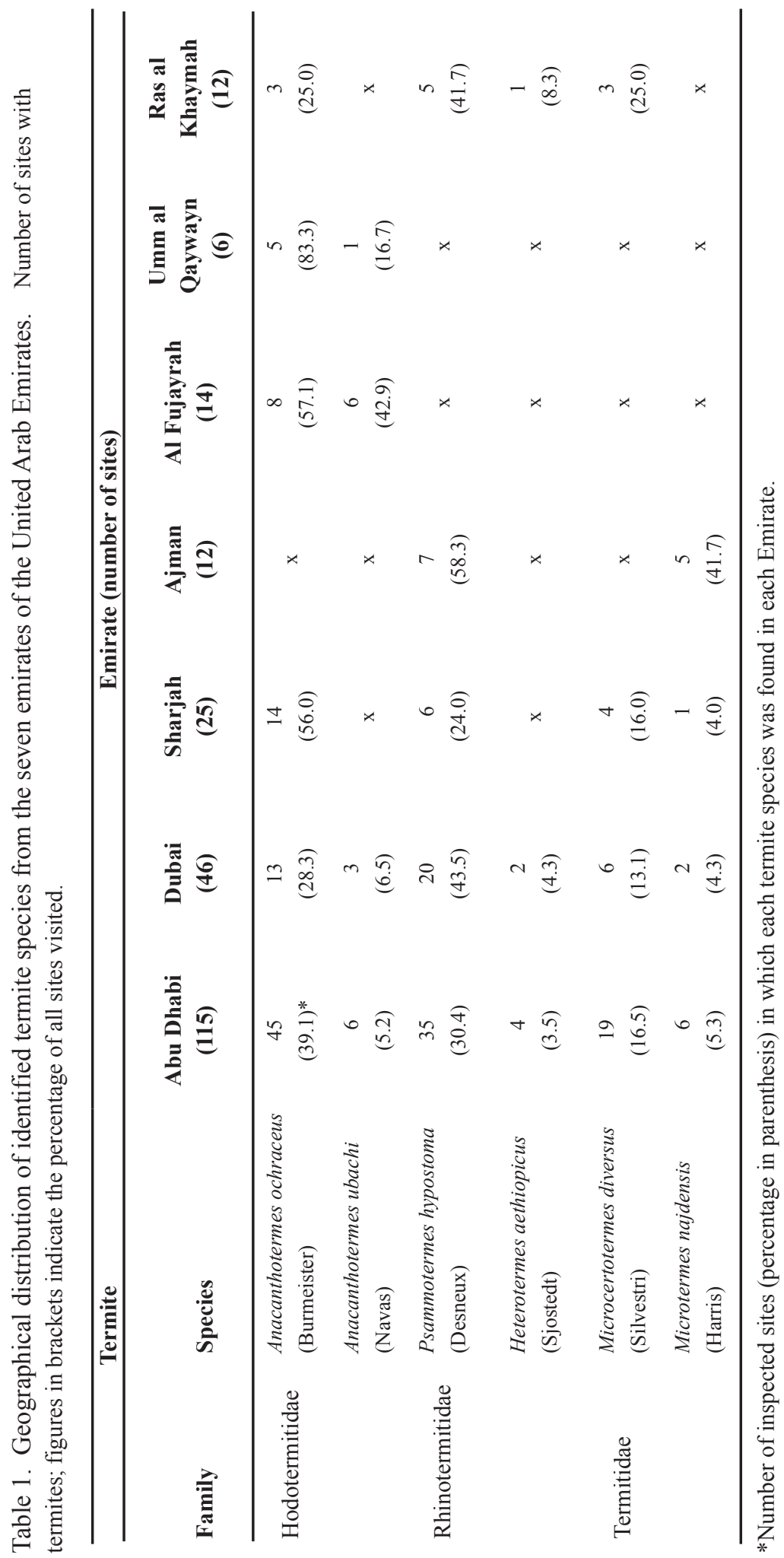


History (UK). Data on the geographical distribution and hosts (plants and other materials) attacked by various termite species, was collected.

\section{Results and Discussion}

\section{Termite species}

Table 1 shows all identified termite species in each Emirate. A total of six termite species, belonging to 5 genera and 3 families, were identified. Termite species were the harvester termites: Anacanthotermes ochraceus (Burmeister) and Anacanthotermes ubachi (Navas), the sand termite Psammotermes hypostoma (Desneux), the small waxy termites Microcerotermes diversus (Silvestri), Heterotermes aethiopicus (Sjostedt), and Microtermes najdensis (Harris). Except for the only record of $H$. aethiopicus in the UAE (Boocock, 1979), the other five species had not previously been reported in the UAE. All species were subterranean in habitat and reach wood sources through earthen gallery systems. Workers of most species forage in the open from late afternoon to early morning. Soldiers appeared to form a small proportion of the termite colonies.

\section{Identification and geographical distribution}

The dominant termite species found in the UAE were $A$. ochraceus, followed by P. hypostoma and $M$. diversus. The distributions of the six termite species in each emirate were as follows: A. ochraceus was found in all emirates, except in Ajman; A. ubachi was found in Abu Dhabi, Dubai, Al Fujayrah and Umm al Qaywayn; P. hypostoma was found in all emirates except in Al Fujayrah; H. aethiopicus was found in Abu Dhabi, and Ras Al Khaymah; M. diversus was found in four emirates of Abu Dhabi, Dubai, Sharjah, and Ras al Khaymah; and M. najdensis was found in Abu Dhabi, Dubai, Sharjah and Ajman.

All identified species were present in Abu Dhabi and Dubai Emirates. A. ochraceus, P. hypostoma, and $M$. diversus were found in $39.1,30.4$, and $16.5 \%$ of the inspected sites in Abu Dhabi and 28.3, 43.5 and $13.5 \%$ of the inspected sites in Dubai. In Sharjah, A. ochraceus, $P$. hypostoma, $M$. diversus, and $M$. najdensis were found. In Ajman, only P. hypostoma and $M$. diversus were found. A. ochraceus and $A$. ubachi were found only in Al Fujayrah and Umm al Qaywayn Emirates. In Ras al Khaymah, A. ochraceus,
P. hypostoma, H. aethiopicus, and M. diversus were found.

\section{Hosts}

Subterranean termites in the UAE are considered pests because of the extent of damage they cause to various sorts of living hosts structural materials. Termites showed host preference as follows:

Termites and residences and historical buildings: Damage to wood in residences and historical buildings was inflicted by all identified species in all emirates, except in the case of $M$. najdensis where there was no record of infestation in buildings. A. ochraceus and $P$. hypostoma were found attacking and destroying roofs of historical buildings and causing damage to constructional timbers and furniture. In many cases these species had removed the straw from mud bricks used in the construction of rural residences, especially in Dubai and Abu Dhabi Emirates. Kassab et al. (1960) reported that a severe infestation by $A$. ochraceus resulted in the abandoning of a village in Egypt.

The damage caused to wood in residences and historical buildings in Abu Dhabi and Dubai Emirates, mainly by A. ochraceus and $P$. hypostoma, justify the application of chemical preservatives and other chemical control strategies such as pressure injection treatments, barrier treatments, and the use of baits.

Termites and fruit trees: Termites in UAE are considered to be pests of fruit trees. Live citrus trees, Citrus sp., were infested by A. ochraceus and $P$. hypostoma in Ras al Khaymah, and M. najdensis in Ajman. Date palm trees, Phoenix dactylifera, were affected by all identified species at various levels of infestation. Live date palm trees were affected by four species: A. ochraceus in Abu Dhabi, Dubai and Al Fujayrah; P. hypostoma in Abu Dhabi; $M$. diversus in Abu Dhabi and Sharjah; and M. najdensis in Abu Dhabi, Dubai and Ajman. Roots and trunks of dead palm trees in all emirates (except Ajman) were infested by all identified species except M. najdensis. The most common form of attack by termites was the hollowing-out of the palm roots, which may be followed by yellowing and death of palm trees, especially young trees and offshoots.

Termites in woodland: Several forest trees were affected by termite damage: Sidr or Nabak (Zizyphus spina-christi), Samur (Acacia tortilis), Ghaf (Prosopis 
Table 2. Primary hosts of termite species identified from each of the seven emirates of the United Arab Emirates.

\begin{tabular}{|c|c|c|c|c|c|c|c|}
\hline \multirow[b]{2}{*}{ Emirate } & \multicolumn{7}{|c|}{ Termite species* } \\
\hline & $\begin{array}{l}\text { Anacantho- } \\
\text { termes } \\
\text { ochraceus } \\
\text { (Burmeister) }\end{array}$ & $\begin{array}{l}\text { Anacantho- } \\
\text { termes } \\
\text { ubachi } \\
\text { (Navas) }\end{array}$ & $\begin{array}{l}\text { Psammo- } \\
\text { termes } \\
\text { hypostoma } \\
\text { (Desneux) }\end{array}$ & $\begin{array}{l}\text { Hetero- } \\
\text { termes } \\
\text { aethiopicus } \\
\text { (Sjostedt) }\end{array}$ & $\begin{array}{l}\text { Microcero- } \\
\text { termes } \\
\text { diversus } \\
\text { (Silvestri) }\end{array}$ & $\begin{array}{l}\text { Micro } \\
\text { termes } \\
\text { najdensis } \\
\text { (Harris) }\end{array}$ & \\
\hline Abu Dhabi & $\begin{array}{l}\text { Aw, DP, Fs, } \\
\text { LP, Nc, Pp, } \\
\text { Rs, Wd, Vg }\end{array}$ & $\begin{array}{l}\text { DP, Nc, Pp, } \\
\text { Rs, Wd }\end{array}$ & $\begin{array}{l}\text { Aw, DP, Fs, } \\
\text { LP, Nc, Pp, } \\
\text { Rs, Wd, Vg }\end{array}$ & $\begin{array}{l}\mathrm{DP}, \mathrm{Fs}, \mathrm{Nc} \\
\text { Pp, Rs, Wd }\end{array}$ & $\begin{array}{l}\text { DP, Fs, LP, } \\
\text { Nc, Pp, Rs, } \\
\text { Wd, Vg }\end{array}$ & $\begin{array}{l}\text { Fs, LP, Nc, } \\
\text { Wd, Vg }\end{array}$ & \\
\hline Dubai & $\begin{array}{l}\text { DP, Nc, Pp, } \\
\text { Rs, Wd }\end{array}$ & Rs, Wd & $\begin{array}{l}\mathrm{DP}, \mathrm{Nc}, \mathrm{Pp} \\
\mathrm{Rs}, \mathrm{Wd}, \mathrm{Vg}\end{array}$ & Rs, Wd & $\begin{array}{l}\text { DP, Pp, } \\
\text { Rs, Wd }\end{array}$ & LP, Wd & \\
\hline Sharjah & $\begin{array}{l}\text { DP, Nc, } \\
\text { Pp, Rs }\end{array}$ & $x$ & $\begin{array}{l}\text { DP, Nc, } \\
\text { Rs, Wd }\end{array}$ & $x$ & $\begin{array}{l}\text { LP, Nc, } \\
\text { Rs, Wd }\end{array}$ & $\mathrm{Wd}$ & \\
\hline Ajman & $\mathrm{x}$ & $\mathrm{x}$ & $\mathrm{Pp}, \mathrm{Rs}, \mathrm{Wd}$ & $\mathrm{x}$ & $\mathrm{x}$ & $\mathrm{Ct}, \mathrm{LP}, \mathrm{Wd}$ & \\
\hline Al Fujayrah & $\begin{array}{l}\text { DP, LP, } \\
\text { Pp, Rs }\end{array}$ & DP, Pp, Wd & $\mathrm{x}$ & $\mathrm{x}$ & $\mathrm{x}$ & $\mathrm{x}$ & \\
\hline $\begin{array}{l}\text { Umm al } \\
\text { Qaywayn }\end{array}$ & DP, Pp, Rs & Wd & $\mathrm{x}$ & $\mathrm{x}$ & $\mathrm{x}$ & $\mathrm{x}$ & \\
\hline $\begin{array}{r}\text { Ras al } \\
\text { Khaymah }\end{array}$ & $\begin{array}{l}\text {,Ct, DP } \\
\text { Pp, Rs }\end{array}$ & & $\begin{array}{r}\text {,Ct, DP, Rs } \\
\mathrm{Wd}, \mathrm{Vg}\end{array}$ & Rs, Wd & DP, Rs, Wd & & $\mathrm{x}$ \\
\hline
\end{tabular}

*Abbreviations of termite hosts: $\mathrm{Aw}=$ Agricultural weeds; $\mathrm{Ct}=$ Citrus; $\mathrm{DP}=$ Dead date palm, Fs = Forest trees; $\mathrm{LP}=$ Live date palm; $\mathrm{Nc}=$ Non-cellulose products; $\mathrm{Pp}=$ papers; $\mathrm{Rs}=$ Residences; $\mathrm{Wd}=$ Wood; $\mathrm{Vg}=$ Vegetable field crops; $\mathrm{x}=$ species not present.

cineraria), Arabean gum (Acacia arabica $[=$ nilotica $]$ ), Ethel or Tamarisk (Tamarix sp.), Arak or Arakh (Salvadora persica). Woodland trees grown in Abu Dhabi Emirate were infested by all identified species except A. ubachi. A. ochraceus was the only species infesting woodland trees in Dubai Emirate.

Termites and vegetable crops: Tomato (Lycopersicon esculentum), okra (Abelinoschus esculentus), pepper (Capsicum annum) and cauliflower (Brassica oleracea botrytis) were the vegetable plants most affected by A. ochraceus in Abu Dhabi; $P$. hypostoma in Abu Dhabi, Dubai and Ras al Khaymah; and M. diversus and M. najdensis in Abu Dhabi. A. ochraceus was collected from the soil surface of dry grass and vegetable debris in the field. This feeding habit gives the Anacathotermes group their alternative name of harvester termites (Harris, 1967).
Termites and agricultural weeds: The only termite species infesting agricultural weeds in date palm plantations, field crops, and dry lands were $A$. ochraceus and P. hypostoma in Abu Dhabi Emirate. The main weeds affected by termites were: amaranthus viridis, Convolvulus arvenis, Cornulaca monacantha, Crotalaria aegyptiaca, Cucumis prophetarum, Cyperus rotundus, Halopyrum mucronatum, Halyoxylon persicum, Phragmites australis, Setaria verticellata, and Zilla spinosa.

Termites and non-cellulose products: Noncellulose items, such as carpets, leather and rubber were affected by all identified species in Abu Dhabi Emirate. A. ochraceus and P. hypostoma also fed on non-cellulose items in Dubai and Sharjah Emirates.

Termites and paper: Paper was infested by $A$. ochraceus in all emirates except Ajman; A. ubachi 
was also found in Abu Dhabi and Al Fujayrah; $P$. hypostoma and M. diversus in Abu Dhabi and Dubai and H. aethiopicus in Abu Dhabi.

Termites and wood: Wood in storage and wood products, such as furniture, were affected by all identified species in all emirates.

The seven emirates of the UAE enclose a total area of about $83,000 \mathrm{~km}^{2}$ lying at the southwestern tip of the Arabian Peninsula between 20 and $26^{\circ} \mathrm{N}$ and 51 and $56^{\circ} \mathrm{E}$. Apart from the mountains, the landscape is dominated by geologically recent sands overlying limestone sediments plus marls, shale deposits and evaporates. Folded sediments occasionally protrude through the sands as isolated hills. The UAE has two coastlines, one to the west and one to the east. The climate is characterized by low rainfall and high temperatures, ideal for termite growth and development.

Rainfall, atmospheric temperature, humidity, vegetation and soil type are the major ecological factors influencing the abundance, distribution and dispersal of termites. The annual rainfall is highly variable. All recorded termite species occur in Abu Dhabi and Dubai, where less than $100 \mathrm{~mm}$ rainfall is usually recorded. Only in those areas where man has a direct influence, as in towns, villages, farms and beside roads, has there been any significant alteration to the desert environment in recent years (Western, 1989). There is a wide-scale attempt to create woodland in parts of the UAE which will increase the range of micro-habitats suitable for subterranean termites, especially A. ochraceus, P. hypostoma, and Microcerotermes diversus.

Nests of termite species recorded in all emirates were of subterranean termites found in arid conditions where there was at least a proportion of clay in the soil and groundwater was enough to support sparse vegetation. Nests of $A$. ochraceus and $P$. hypostoma consisted of complex systems with several interconnecting galleries. Nests of other termite species consisted of diffuse systems of small cells at various depths with interconnecting galleries. $A$. ochraceus and P. hypostoma comprised over $70 \%$ of the termites recorded in the largest two emirates, Abu Dhabi and Dubai (Table 2). A. ochraceus fed largely on dry grass and other vegetable debris, but it has been reported to damage rural buildings, soft timers, palm thatch and mud bricks (Harris, 1967). P. hypostoma preferred non-cultivated areas with little vegetation and sandy soil through which water rapidly percolates, and where it would be possible to construct tunnels to the water table which may be at a depth of $10 \mathrm{~m}$. The presence of $P$. hypostoma at a depth of 30-40 m has been reported (Howse, 1970). The species tend to be less common in areas where the soil has a high clay fraction (Harris, 1970). The nest structure and microclimate of $P$. hypostoma has been described by Noirot (1970). The nest pattern of P. hypostoma differed greatly, particularly as to depth, in different localities (Abu Dhabi to Ras al Khaymah), presumably in relation to humidity and temperature. It is reported to replace A. ochraceus in areas of high temperature and with a sandy terrain (Harris 1970). P. hypostoma fed on wood, vegetable debris and on living plants. They are found attacking and destroying roofs of historical buildings and residences in Abu-Dhabi and Dubai Emirates.

The present survey was the first attempt to identify the termite fauna of the UAE. Future studies on subterranean termites in the UAE are needed, such as population dynamics of the identified termites on their hosts, correlation of termite distribution with the type of soil and temperature, the extent of damage inflicted on local and imported woods by the identified termites and development of new control strategies to combat termite problems.

\section{Acknowledgment}

I appreciate the assistance of all field workers in the Department of Agriculture and Livestock in Al-Ain, the Municpalities (Al-Ain, Abu Dhabi and Dubai), and the Ministry of Agriculture and Fisheries for collecting termites in various emirates. This research project (No. 03-6-11/00) was funded by the Scientific Research Council of the United Arab Emirate University.

\section{References}

Badawi, A., A. Dabbour nd A. Faragalla. 1982. A contribution to the termite fauna (Isoptera) of Saudi Arabia. Sociobiology 7:259-260.

Badawi, A., H. Al-Kady and A. Faragalla. 1986. Termites (Isoptera) of Saudi Arabia, their hosts and geographical distribution. Journal of Applied Entomology 101:413-420.

Boocock, D. 1979. Termites. Emirates Natural History Group Bulletin 8:27-28.

Chhotani, O.B. and G. Bose. 1982. Insects of Saudi Arabia, Isoptera. Fauna of Saudi Arabia 4:73-83. 
Chhotani, O.B. and G. Bose. 1991. Isoptera from Saudi Arabia and Kuwait, with a key to Arabian species. Fauna of Saudi Arabia 12:256-265.

Fontes, L.R. 1985. New genera and new species of Nasutitermitinae from the Neotropical region (Isoptera, Termitidae). Review of Brasilian Zoology 3:7-25.

Harris, W.V. 1967. Termites of the genus Anacanthotermes in North Africa and the Near East (Isoptera: Hodotermitidae). Proceedings of the Royal Entomological Society of London (B) 36:79-86.

Harris, W.V. 1970. Termites of the Palearetic region. In: Biology of Termites, K. Krishna and F. M. Weesner (Editors) 2:295-314. Academic Press, London.

Howse, P.E. 1970. Termites: A Study in Social Behaviour. Hutchinson Univ. Library. London.

Kassab, A., M.I. Hassan, A.M. Chaarawi and A.M. Shahwan. 1960. The termite problem in Egypt with special reference to control. Ministry of Agriculture. Cairo, Egypt.
Myles, T.G. 2004. Proposed taxonomy of the order Isoptera. In: http://www.utoronto.ca/forest/termite/ taxon.htm.

Nasr, H., A. Halawani, F. Al-Hadidi and B. Yahia. 1978. Survey of termite species in the Western Region of Saudi Arabia. Technical Report, Agriculture Research Center, Western Region, Ministry of Agriculture and Water, Saudi Arabia, pp46-64.

Noirot, C. 1970. The nests of termites. In: Biology of Termites, K Krishna and F.M. Weesner (Editors), 2:73-125. Academic Press, London.

Sands, W.A. 1998. The Identification of Worker Castes of Termite Genera from Soil of Africa and the Middle East. CAB International, Wallingford, UK.

Snyder, T. 1949. Catalog of the Termites of the World. Smithsonian Miscellaneous Collection 112:1-490.

Western, R.R. 1989. The Flora of the United Arab Emirates: An Introduction. UAE University Publication. Al-Ain, UAE.

Received: February 2005

Accepted: June 2005 